\title{
Gender-Specific Distribution of Hematological Parameters in Adults Living in Nouna, Burkina Faso
}

\author{
T. Böhler*,a, G. Kynast-Wolf ${ }^{b}$, B. Coulibaly ${ }^{c}$, A. Siè ${ }^{c}$ and A. Kapaun ${ }^{b}$ \\ ${ }^{a}$ Department of Virology, and ${ }^{b}$ Department of Tropical Medicine and Public Health, University of Heidelberg, Germany, \\ ${ }^{c}$ Nouna Health Research Centre, Nouna, Burkina Faso
}

\begin{abstract}
We examined the distribution of hematological parameters in 186 adults ( 89 female, 97 male) living in Nouna, Burkina Faso. Median $\left(5^{\text {th }}-95^{\text {th }}\right.$ percentile) hemoglobin concentration was 12.6 [10.3-15.3] g/dl, which was lower than reported from other populations in Africa. Iron deficiency may be the most important reason for this observation.
\end{abstract}

Keywords: Anemia, hemoglobin, red blood cell indices, malaria, iron deficiency.

There is ample evidence that clinicians and medical researchers should use method-specific reference ranges in their laboratories which account for gender differences and variances in the ethnic composition of the local society [1]. In particular, reference ranges of hematological indices based on results from western individuals are not in agreement with those calculated from African populations [2].

From July 2004 to September 2005 a study was performed by the Nouna Health Research Center (Centre de la Recherche en Santé de Nouna, CRSN) in order to generate gender-specific reference values for immunological parameters which could be used in immunological monitoring of individuals living with HIV/AIDS [3]. We now analysed data on hematological parameters in order to assess the distribution of the measurements in our study population.

\section{STUDY DESIGN}

The study was part of an ongoing longitudinal trial on the prevention of mother-to-child transmission of the human immune deficiency virus in Nouna [4] which was approved by the Institutional Ethics Committee of the University of Heidelberg, Germany and the Institutional Ethics Committee at the CRSN. Donors were recruited after informed consent from female clients of the mother and infant clinic at the Nouna Health Center and during three blood donation campaigns in the community of Nouna town. Details of the study protocol are described elsewhere [3].

Any positive serological test for the presence of antibodies against HIV or syphilis as well as for HBsAg led to exclusion from the study. In addition, based on history and physical examination, eligible donors were classified as "clinically healthy", i.e. they did not show or report signs and symptoms of illness $(>5 \mathrm{~kg}$ weight loss in the preceding month, fever during the last 2 weeks, asthma, diabetes, cardiovascular and renal diseases). Clinically inapparent chronic conditions (e.g., hepatitis) were not specifically screened for by laboratory testing.

*Address correspondence to this author at the c/o Department of Virology, University of Heidelberg, Im Neuenheimer Feld 324, D-69120 Heidelberg, Germany; Tel: +49-6221 565002; Fax +49-6221 565003;

E-mail: thomas.boehler@med.uni-heidelberg.de
An automated device (Sysmex KX21N, Sysmex Corporation, Kobe, Japan) was used to measure erythrocyte count (RBC), hemoglobin concentration (Hb), hematocrit (Hct), $\mathrm{RBC}$ mean corpuscular volume (MCV), mean corpuscular hemoglobin $(\mathrm{MCH})$, and mean corpuscular hemoglobin concentration (MCHC), platelet count (PLT), total leukocyte count (WBC), and the automated white blood differential (percentages of lymphocytes (LYM), neutrophils (NEUT), and the mixed population of monocytes, basophiles and eosinophiles [MXD]). The measurements were performed on $50 \mu 1$ of whole blood collected via venipuncture into EDTA. Quality control was done at regular intervals using EIGHTCHECK 3 WP high, low and normal manufactured by Sysmex.

Descriptive statistics were calculated using SAS for Windows; for comparison between male and female subjects the TTEST procedure and for comparison between different age groups linear regression analysis (GLM procedure) was used.

\section{RESULTS AND DISCUSSION}

Data from 186 adults ( 89 female, 97 male) aged 18 to 78 years were available for final analysis (Table 1). Age distribution was as follows: $<20$ years, $\mathrm{n}=28$ (19 female, 9 female); 20 to 29 years, $\mathrm{n}=99$ (59 female, 40 male); 30 to 39 years, $\mathrm{n}=31$ (16 female, 15 male); 40 years and more, $\mathrm{n}=$ 28 (14 female, 14 male). Male blood donors had significantly higher RBC counts than females (mean difference: $0.5 * 10^{12} / \mathrm{l}, 95 \%$ CI: 0.3 to $\left.0.6 * 10^{12} / \mathrm{l} ; \mathrm{p}<0.0001\right)$, higher $\mathrm{Hb}$ values (mean difference: $1.7 \mathrm{~g} / \mathrm{dl}, 95 \% \mathrm{CI}: 1.4$ to $2.1 \mathrm{~g} / \mathrm{dl}$; $\mathrm{p}<0.0001$ ), and a higher Hct (mean difference: 0.05 1/l, $95 \%$ CI: 0.04 to $0.061 / 1 ; p<0.0001$ ). No statistically significant influence of age on hematological parameters could be detected in our cohort.

$\mathrm{RBC}, \mathrm{Hb}$, and Hct values in Nouna were lower than those reported from other African populations (Table 2). Gender-specific differences (female<male) were similar to those published in the literature [5-7]. Beutler and Waalen recently suggested specific lower limits of normal $\mathrm{Hb}$ concentrations for black US-American males $(12.9 \mathrm{~g} / \mathrm{dl})$ and females $(11.5 \mathrm{~g} / \mathrm{dl})$ [8]. When we applied those limits to our study population, approximately $30 \%$ of all clinically healthy adults in Nouna were classified as anemic. 
Table 1. Distribution of Values for Hematological Parameters Obtained from Healthy Adults in Nouna, Burkina Faso. The Marker "§" Indicates a Statistically Significant Difference Between Males and Females $(\mathbf{p}<0.01)$

\begin{tabular}{|c|c|c|c|c|c|c|c|c|c|c|c|}
\hline Total $(n=186)$ & $\begin{array}{l}\text { RBC§ } \\
\left(10^{12} / 1\right)\end{array}$ & $\begin{array}{l}\text { Hb§ } \\
(\mathrm{g} / \mathrm{dl})\end{array}$ & $\begin{array}{c}\text { Hct } \\
(1 / /)\end{array}$ & $\begin{array}{c}\text { MCV } \\
\text { (fl) }\end{array}$ & $\begin{array}{c}\text { MCH } \\
\text { (pg) }\end{array}$ & $\begin{array}{c}\text { MCHC } \\
\text { (g/dl) }\end{array}$ & $\begin{array}{c}\text { PLT } \\
\left(10^{9} / 1\right)\end{array}$ & $\begin{array}{l}\text { WBC } \\
\left(10^{9} / 1\right)\end{array}$ & $\begin{array}{c}\text { LYM } \\
(\%)\end{array}$ & $\begin{array}{c}\text { MXD } \\
(\%)\end{array}$ & $\begin{array}{c}\text { NEUT } \\
(\%)\end{array}$ \\
\hline $95^{\text {th }}$ centile & 5.4 & 15.3 & 0.44 & 92 & 32 & 36.2 & 356 & 8.5 & 59 & 20 & 63 \\
\hline $75^{\text {th }}$ centile & 4.8 & 13.8 & 0.40 & 88 & 30 & 35.2 & 281 & 5.9 & 50 & 14 & 51 \\
\hline $50^{\text {th }}$ centile (median) & 4.4 & 12.6 & 0.37 & 85 & 29 & 34.4 & 236 & 5.2 & 44 & 11 & 45 \\
\hline $5^{\text {th }}$ centile & 3.6 & 10.3 & 0.31 & 75 & 24 & 31.7 & 146 & 3.4 & 27 & 6 & 28 \\
\hline \multicolumn{12}{|l|}{ Male $(n=97)$} \\
\hline $95^{\text {th }}$ centile & 5.6 & 15.6 & 0.46 & 94 & 33 & 36.3 & 365 & 9.2 & 60 & 22 & 64 \\
\hline $75^{\text {th }}$ centile & 5.0 & 14.3 & 0.41 & 88 & 31 & 35.5 & 271 & 5.9 & 50 & 15 & 52 \\
\hline $5^{\text {th }}$ centile & 3.8 & 11.3 & 0.34 & 73 & 25 & 31.7 & 127 & 3.2 & 26 & 4 & 27 \\
\hline \multicolumn{12}{|l|}{ Female $(\mathrm{n}=89)$} \\
\hline $95^{\text {th }}$ centile & 4.9 & 13.5 & 0.39 & 92 & 32 & 36.1 & 356 & 7.4 & 57 & 18 & 62 \\
\hline $75^{\text {th }}$ centile & 4.5 & 12.5 & 0.37 & 87 & 30 & 35.0 & 291 & 5.9 & 49 & 14 & 51 \\
\hline $50^{\text {th }}$ centile (median) & 4.2 & 12.0 & 0.35 & 84 & 28 & 34.2 & 252 & 5.2 & 43 & 11 & 46 \\
\hline $25^{\text {th }}$ centile & 3.9 & 11.0 & 0.33 & 80 & 27 & 32.9 & 214 & 4.5 & 37 & 9 & 39 \\
\hline $5^{\text {th }}$ centile & 3.5 & 9.8 & 0.30 & 75 & 24 & 31.4 & 159 & 3.4 & 27 & 7 & 30 \\
\hline
\end{tabular}

Abbreviations: $\mathrm{RBC}=$ erythrocyte count, $\mathrm{Hb}=$ hemoglobin concentration, $\mathrm{Hct}=$ hematocrit, $\mathrm{MCV}=$ mean corpuscular volume, $\mathrm{MCH}=$ mean cellular hemoglobin, $\mathrm{MCHC}=$ mean cellular hemoglobin concentration, PLT $=$ thrombocyte count, $\mathrm{WBC}=$ leukocyte count, $\mathrm{LYM}=$ lymphocytes, MXD $=$ monocytes, eosinophiles and basophiles, NEUT $=$ neutrophils.

Table 2. Comparison of the Distribution of Values for Hematological Parameters Retrieved from Distinct Populations in Burkina Faso (Present Study), Ethiopia [5], Uganda [7], the Central African Republic (CAR) [6], and the USA (Black Americans) [9]. Data are Given as Median and $5^{\text {th }}$ and $95^{\text {th }}$ Centiles Unless Otherwise Indicated

\begin{tabular}{|c|c|c|c|c|c|c|c|c|c|c|c|c|}
\hline $\begin{array}{l}\text { Region } \\
\text { (range of } \\
\text { age) }\end{array}$ & $\operatorname{sex}$ & $\begin{array}{c}\text { RBC } \\
\left(10^{12} / \mathbf{l}\right)\end{array}$ & $\mathrm{Hb}(\mathrm{g} / \mathrm{dl})$ & Het (1/l) & $\operatorname{MCV}$ (fl) & $\begin{array}{c}\text { MCH } \\
(\mathbf{p g})\end{array}$ & $\begin{array}{c}\text { MCHC } \\
(\mathrm{g} / \mathrm{l})\end{array}$ & $\begin{array}{c}\text { PLT } \\
\left(10^{9} / \mathrm{l}\right)\end{array}$ & $\begin{array}{c}\text { WBC } \\
\left(10^{9} / 1\right)\end{array}$ & $\begin{array}{c}\text { LY } \\
\left(10^{9} / \mathbf{l}\right)\end{array}$ & $\begin{array}{l}\text { LY } \\
(\%)\end{array}$ & $\begin{array}{c}\text { NEUT } \\
(\%)\end{array}$ \\
\hline \multirow{2}{*}{$\begin{array}{l}\text { Burkina Faso } \\
\text { (18-78 years) } \\
n=186\end{array}$} & M & $\begin{array}{c}4.7 \\
(3.8-5.6)\end{array}$ & $\begin{array}{c}13.5 \\
(11.3-15.6)\end{array}$ & $\begin{array}{c}0.39 \\
(0.34-0.46)\end{array}$ & $\begin{array}{c}85 \\
(73-94)\end{array}$ & $\begin{array}{c}29 \\
(25-33)\end{array}$ & $\begin{array}{c}34.6 \\
(31.7-36.3)\end{array}$ & $\begin{array}{l}217 \\
(127- \\
365)\end{array}$ & $\begin{array}{c}5.1 \\
(3.2-9.2)\end{array}$ & $\begin{array}{c}2.1 \\
(1.3-4.0)\end{array}$ & $\begin{array}{c}44 \\
(26-60)\end{array}$ & $\begin{array}{c}43 \\
(27-64)\end{array}$ \\
\hline & $\mathrm{F}$ & $\begin{array}{c}4.2 \\
(3.5-4.9)\end{array}$ & $\begin{array}{c}12.0 \\
(9.8-13.5)\end{array}$ & $\begin{array}{c}0.35 \\
(0.30-0.39)\end{array}$ & $\begin{array}{c}84 \\
(75-92)\end{array}$ & $\begin{array}{c}28 \\
(24-32)\end{array}$ & $\begin{array}{c}34.2 \\
(31.4-36.1)\end{array}$ & $\begin{array}{l}252 \\
(159- \\
356)\end{array}$ & $\begin{array}{c}5.2 \\
(3.4-7.4)\end{array}$ & $\begin{array}{c}2.2 \\
(1.4-3.2)\end{array}$ & $\begin{array}{c}43 \\
(27-57)\end{array}$ & $\begin{array}{c}46 \\
(30-62)\end{array}$ \\
\hline \multirow{2}{*}{$\begin{array}{l}\text { Uganda } \\
\begin{array}{l}\text { (25-92 years) } \\
n=845\end{array}\end{array}$} & M & $\begin{array}{c}4.9 \\
(3.8-6.0)\end{array}$ & $\begin{array}{c}14.1 \\
(11.1-16.8)\end{array}$ & $\begin{array}{c}0.41 \\
(0.32-0.48)\end{array}$ & $\begin{array}{c}84 \\
(70-95)\end{array}$ & NA & NA & $\begin{array}{c}171 \\
(80-288)\end{array}$ & \multirow{2}{*}{$\begin{array}{c}5.3 \\
(3.4-8.7)\end{array}$} & \multirow{2}{*}{$\begin{array}{c}2.4 \\
(1.4-4.2)\end{array}$} & \multirow[b]{2}{*}{ NA } & \multirow[b]{2}{*}{ NA } \\
\hline & $\mathrm{F}$ & $\begin{array}{c}4.5 \\
(3.7-5.3)\end{array}$ & $\begin{array}{c}12.5 \\
(10.1-14.3)\end{array}$ & $\begin{array}{c}0.36 \\
(0.30-0.41)\end{array}$ & $\begin{array}{c}81 \\
(68-93)\end{array}$ & NA & NA & $\begin{array}{l}198 \\
(100- \\
297)\end{array}$ & & & & \\
\hline
\end{tabular}


(Table 2). Contd......

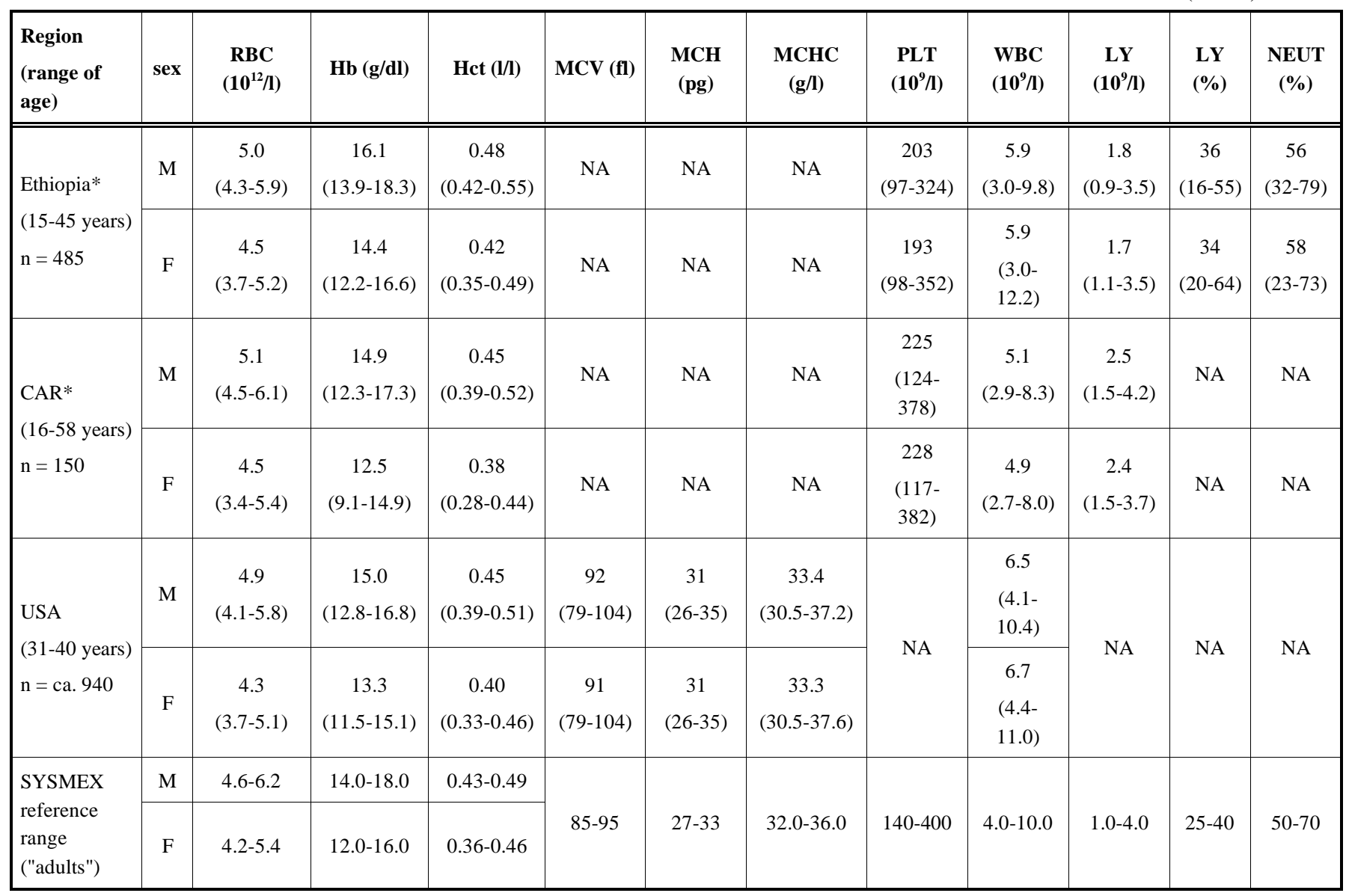

${ }^{*}$ median \pm 2 standard deviations or $2.5^{\text {th }}$ and $97.5^{\text {th }}$ centiles; Abbreviations: $\mathrm{M}=$ male, $\mathrm{F}=$ female, $\mathrm{RBC}=$ erythrocyte count, $\mathrm{Hb}=$ hemoglobin concentration, Hct $=$ hematocrit, $\mathrm{MCV}$ $=$ mean corpuscular volume, $\mathrm{MCH}=$ mean cellular hemoglobin, $\mathrm{MCHC}=$ mean cellular hemoglobin concentration, $\mathrm{PLT}=$ thrombocyte/platelet count, $\mathrm{WBC}=$ leukocyte count, $\mathrm{LY}=$ lymphocytes, NEUT = neutrophils, NA = not available.

Comparison our data on mean corpuscular volume with MCV percentiles for black Americans living in the metropolitan area of Washington, D.C. revealed a tendency towards microcytosis in our study population: median $\mathrm{MCV}$ $\left(50^{\text {th }}\right.$ percentile) was in the range of the $25^{\text {th }} \mathrm{MCV}$ percentile of black Americans [9]. The ratio of MCV (fl) over RBC $\left(10^{6}\right.$ cells $\left.\mu l^{-1}\right)$ [10] was $>14$ in all study participants, indicating that iron deficiency may be the most important reason for microcytic anemia in healthy adults in Nouna. No data are yet available, however, on the prevalence of iron deficiency, or on the frequency of diseases that may cause iron deficiency, e.g. infestation with hookworms. We do not know the prevalence of hookworms in Nouna, but infestation with helminths was not associated with anemia in pregnant women in Uganda [11].

Malaria is a frequent cause of clinically apparent anemia in Nouna and infection with Plasmodium species is highly prevalent after the rainy season (approximately $80 \%$ as detected by microscopic examination of thick blood films and more than $90 \%$ by PCR techniques) [12]. The persistence of submicroscopic Plasmodium gametocyte carriage which has been shown to be common in an area of low and seasonal transmission [13] may lead to increased hemolysis and clearance of uninfected erythrocytes and have also have a negative impact on hematopoesis [14].

Previous studies had revealed a high prevalence $(29.8 \%)$ of abnormal hemoglobins in the study area, but the fre- quency of thalassaemia was very low and only the carriers of hemoglobin SC (present in $1.2 \%$ of the female population) had a high risk of being anemic [15]. Other potential genetic causes of hereditary anemia such as glucose-6-phosphatedehydrogenase deficiency or glutathion reductase deficiency were diagnosed in $6-16 \%$ of the study population but these enzymopathies do not cause microcytic anemia [16].

We do not know whether the distribution of hematological parameters in our study population shows seasonal changes; this question requires further study. Another potential limitation of data interpretation relates to the fact that we did not specifically screen for clinically inapparent chronic diseases and relied on history and assessment of symptoms when recruiting our healthy study population. We do not expect, however, that failure to exclude rare cases of chronic diseases does significantly change the results of our study. Gender-specific distribution of $\mathrm{RBC}, \mathrm{Hb}$, and Hct values in adults in Nouna was lower than the reference ranges reported for black US-American adults and also below those of other populations in Africa. Iron deficiency may be the most important explanation for this observation.

The clinical consequences of low RBC, Hb and Hct values in African adults should be studied in more detail. Recent epidemiological data from the US showed that anemia was significantly associated with increased risk of death and mobility disability only in older whites while older blacks with anemia were not at risk for adverse events [17]. Thus, 
the question "what is the lower limit of normal of the blood haemoglobin concentration" [8], eventually has to be answered differently for people living in areas where anemia, malaria, iron deficiency and high mortality rates prevail.

\section{ACKNOWLEDGEMENT}

This study was supported by Deutsche Forschungsgemeinschaft (SFB 544, project A6). We are indebted to all blood donors for their willingness to participate in the study, to Nele Klose for help with data collection, and to Dr. Jean Ganamé and the staff nurses at the PMTCT service of the CMA Nouna for providing blood samples and clinical information.

\section{REFERENCES}

[1] Wakeman L, Al-Ismail S, Benton A, et al. Robust, routine haematology reference ranges for healthy adults. Intern J Lab Hematol 2007; doi: 10.1111/j.1365-2257.2006.00883.x.

[2] Quinto L, Aponte JJ, Sacarlal J, et al. Haematological and biochemical indices in young African children: in search of reference intervals. Trop Med Int Health 2006; 11: 1741-8.

[3] Klose N, Coulibaly B, Tebit DM, et al. Immunohematological reference values for healthy adults in Burkina Faso. Clin Vaccine Immunol 2007; 14: 782-4

[4] Tebit DM, Ganame J, Sathiandee K, Nagabila Y, Coulibaly B, Kräusslich HG. Diversity of HIV in rural Burkina Faso. J Acquir Immune Defic Syndr 2006; 43: 144-52.

[5] Tsegaye A, Messele T, Tilahun T, et al. Immunohematological reference ranges for adult Ethiopians. Clin Diagn Lab Immunol 1999; 6: 410-4.

[6] Menard D, Mandeng MJ, Tothy MB, Kelembho EK, Gresenguet G, Talarmin A. Immunohematological reference ranges for adults from the Central African Republic. Clin Diagn Lab Immunol 2003; 10: 443-5.

[7] Lugada ES, Mermin J, Kaharuza F, et al. Population-based hematologic and immunologic reference values for a healthy Ugandan population. Clin Diagn Lab Immunol 2004; 11: 29-34.

[8] Beutler E, Waalen J. The definition of anemia: what is the lower limit of normal of the blood hemoglobin concentration? Blood 2006; 107: 1747-50.

[9] Castro OL, Haddy TB, Rana SR. Age- and sex-related blood cell values in healthy black americans. Pub Health Rep 1987; 102: 2327.

[10] Mentzer WC. Differentiation of iron deficiency from thalassaemia trait. Lancet 1973; 1(7808): 882 .

[11] Muhangi L, Woodburn P, Omara M, et al. Associations between mild-to-moderate anaemia in pregnancy and helminth, malaria and HIV infection in Entebbe, Uganda. Trans R Soc Trop Med Hyg 2007; doi: 10.1016/j.trstmh.2007.03.017.

[12] Stich A, Oster N, bdel-Aziz IZ, et al. Malaria in a holoendemic area of Burkina Faso: a cross-sectional study. Parasitol Res 2006; 98: 596-9.

[13] Shekalaghe SA, Bousema JT, Kunei KK, et al. Submicroscopic Plasmodium falciparum gametocyte carriage is common in an area of low and seasonal transmission in Tanzania. Trop Med Int Health 2007; 12: 547-53.

[14] Lamikanra AA, Brown D, Potocnik A, Casals-Pascual C, Langhorne J, Roberts DJ. Malarial anemia: of mice and men. Blood 2007; 110: 18-28.

[15] Minet J-C, Sauerborn R, Kanyel S, Ludwig R, Kone B, Diesfeld HJ. Einfluss der mütterlichen Hämoglobinopathien auf Geburtsgewicht und andere neonatale Parameter. Sozialpädiatrie 1991; 13: 582-4.

[16] Coulibaly B. Ph.D. thesis. University of Heidelberg, Germany; 2004.

[17] Patel KV, Harris TB, Faulhaber M, et al. Racial variation in the relationship of anemia with mortality and mobility disability among older adults. Blood 2007; 109: 4663-70. 